\title{
NOSSIS' AUTO-EPITAPH: ANALYSING A CONTROVERSIAL EPIGRAM
}

\begin{abstract}
Summary: Nossis' auto-epitaph is one of the most important texts in Nossis' corpus, and yet one of the most controversial. This paper offers a careful analysis of the text and focuses on the programmatic reuse of epigraphic models and structures, which leads here to a complete subversion of the epitymbion schema. In addition, a thorough analysis is offered for the corrupted passages in the last couplet.
\end{abstract}

Key words: Nossis, auto-epitaph, Hellenistic epigram, Sappho, sphragis, funerary epigram, 'Simon.' AP VII 249, poetic manifesto

Antipater from Thessalonika (AP IX $29=G P h$ 175-184) ${ }^{1}$ included Nossis, an epigrammatist from Epizephyrian Locri, who lived in the first half of the 3rd c. BC, in the canon of the nine most excellent poetesses. All that survives from the hand of Nossis are twelve tetrastich epigrams, which are preserved in different books of the Greek Anthology. Like many other contemporary poets, Nossis must have consciously organized this corpus into a poetic collection, as revealed by the dense network of cross references among her epigrams. ${ }^{2}$ Though scholars have so far paid scarce attention to her work, Nossis' anthology occupies a significant place in the history of early Hellenistic poetry and in the development of the epigrammatic genre.

Within Nossis' corpus, one of the most controversial poems is her auto-epitaph (AP VII $718=H E$ 2831-2834), which must have served as the Schlussgedicht in the

\footnotetext{
${ }^{1}$ On this epigram, see BurZACCHINI, G.: Sul 'canone' delle poetesse (Antip. Thess. AP IX 26 [= XIX G.P.]). Eikasmos 8 (1997) 125-134.

${ }^{2}$ The hypothesis that Nossis organized her epigrams into an anthology was first suggested by ReITZENSTEIN, R.: Epigramm und Skolion. Ein Beitrag zur Geschichte der Alexandrinischen Dichtung. Giessen 1893, 139-140. On the arrangement of epigrams into poetic collections by Hellenistic poets, see GutZWILler, K. J.: Poetic Garlands. Hellenistic Epigrams in Context. Berkeley - Los Angeles - London 1998, in particular 76-88 on Nossis' libellus.
} 
poetic collection of the Locrian poetess. ${ }^{3}$ Scholars commonly agree that these four lines have a prominent position in Nossis' work. ${ }^{4}$ However, the correct meaning and value of these verses have not yet been properly investigated. First of all, the text is corrupted in several places - especially in the final couplet, which is printed for the most part between cruces in Gow and Page's edition. ${ }^{5}$ Furthermore, the text presents serious exegetic difficulties and several questions arise from Nossis' auto-epitaph. In particular, the enigmatic combination of a sepulchral form with a non-sepulchral content has frequently been the source of misinterpretation. This paper will present a careful revision and analysis of the text, with a specific focus on the re-use of funeral themes for literary purposes. The aim is to lead to a better understanding of these programmatic verses and to contribute in this way to a better interpretation of Nossis' work and to an understanding of her place in the history of Greek epigram and literature.

\footnotetext{
${ }^{3}$ REITZENSTEIN (n. 2) 139-140 was the first to suggest that the epigram served as the Schlussgedicht in Nossis' poetic collection.

${ }^{4}$ After REITZENSTEIN (n. 2) 139-140, the epigram has been normally acknowledged as the Schlussgedicht of Nossis' book of epigrams. For a commentary of these verses, see WILAMOWITZ, U.: Hellenistische Dichtung in der Zeit des Kallimachos. I. Berlin 1924, 135-136; GABATHULER, M.: Hellenistische Epigramme auf Dichter. Diss. Basel (St. Gallen) 1937, 7 and 48-49; LUCK, G.: Die Dichterinnen der griechischen Anthologie. MH 11 (1954) 186-187; Gow, A. S. F. - PAGE, D. L.: The Greek Anthology. [I.] Hellenistic Epigrams. Vol. I-II. Cambridge 1965, II 442; GIGANTE, M.: Nosside. PP 29 (1974) 22-39; SPECCHIA, O.: Nosside. Rudiae V (1993) 27-29. The textual problems in the last couplet have been specifically addressed by CAZZANIGA, I.: Critica testuale ed esegesi a Nosside $A$. P. VII, 718. PP 25 (1970) 431-445 and GALLAVOTTI, C.: L'epigramma biografico di Nosside come esempio di critica testuale. In Studi filologici e storici in onore di V. De Falco. Napoli 1971, 239-250. SKINNER, M. B.: Sapphic Nossis. Arethusa 22/1 (1989) 5-18; BowmAN, L.: Nossis, Sappho and Hellenistic poetry. Ramus 27 (1998) 39-59; and SKINNER, M. B.: Nossis Thêlyglôssos: the private text and the public book. In GREENE, E. (ed.): Women Poets in Ancient Greece and Rome. Norman 2005, 126-127 focused instead on the relation with the Sapphic model and the programmatic claim of it. GUTZWILLER (n. 2) pays particular attention to the relation of the epigram to the other epigrams that the poetess must have gathered together in a book. For the text, the main editions that have been taken into account are BRUNCK, R. F. P.: Analecta veterum poetarum Graecorum. Vol. I. Argentorati 1772, 196; MeINEKE, A.: Delectus poetarum Anthologiae Graecae. Berolini 1842, 9; DÜBNER, F.: Epigrammatum Anthologia Palatina cum Planudeis et Appendice nova epigrammatum veterum ex libris et marmoribus ductorum. Vol. I. Parisiis 1864, 411; STADTMÜLLER, H.: Anthologia Graeca epigrammatum Palatina cum Planudea. II/1. Lipsiae 1899, 498-499; WALtz, P.: Anthologie Grecque. Tome V. Paris $1960^{2}$, 158; BECKBY, H.: Anthologia Graeca. Vol. I-IV. München $1966^{2}\left(1957 / 1958^{1}\right)$ II 422; Gow-PAGE (n. 4) II 442.

${ }^{5}$ See Gow-Page (n. 4) I 154.
} 


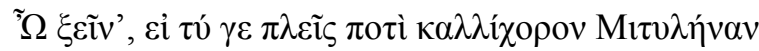

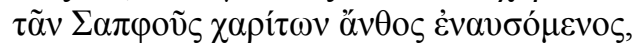

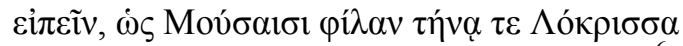

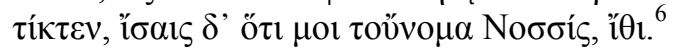

$A P$ VII 718 (f. 321)

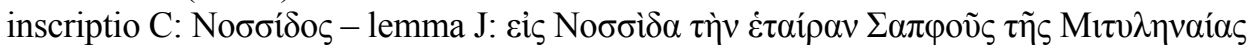

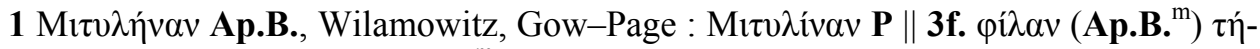

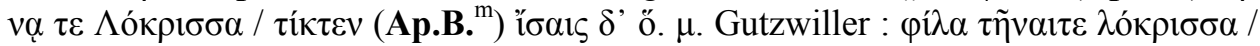

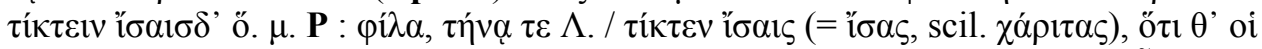

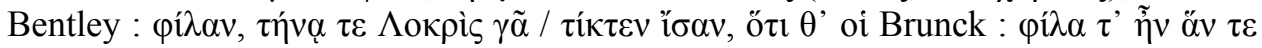

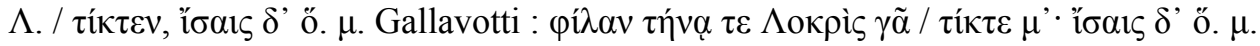
Page ( $\tau$ ík $\tau \varepsilon \mu$ ' coni. Meineke) : alii alia

The epigram opens with an invocation to the 'stranger' appointed with the task of conveying the news to Mitylene, Sappho's homeland, that a Locrian woman has given birth to a poetess, dear to the Muses and to Sappho herself. It is Nossis herself speaking, affixing her name in the last line.

The poem shows the typical features of the epitymbion and in particular of that genre of epitaphs which aim to commemorate those who perished away from home and who ask for the news of their death to be brought back to their homeland. ${ }^{7}$ The most famous model constantly re-employed for this kind of epitaph is the 'Simonidean' epitaph for the fallen at Thermopylae, $A P$ VII 249 (FGE 776f.) ' $\Omega$ $\xi \varepsilon i v ', \dot{\alpha} \gamma \gamma \varepsilon \dot{\lambda} \lambda-$

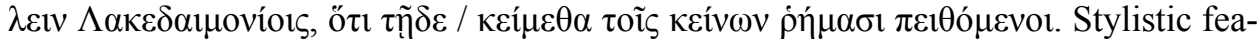
tures and elements related to this famous epitaph recur in a series of epitaphs from the Hellenistic epoch, which, like Nossis' epigram, re-elaborate the motif of conveying a message. ${ }^{8}$ Among these recurrent elements, we find the initial invocation to the stranger, the allusion (in a temporal-conditional sentence) to the journey - generally a sea travel - that the messenger will accomplish, and finally the invitation expressed through a jussive infinitive and direct speech. ${ }^{9}$

Although Nossis plays with the norms of the sepulchral inscriptions, the epi-

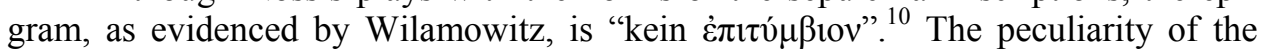

6 "If you, stranger, are sailing to Mitylene where dances are lovely / in order to borrow the flower of Sappho's graces / announce that a Locrian woman bore one dear to the Muses / and to her. You should know that my name is Nossis. Now go." English translation by GUTZWILLER (n. 2) 86.

${ }^{7}$ See Gow-PAGE (n. 4) II 442.

${ }^{8}$ S. L. TARÁN (The Art of Variation in the Hellenistic Epigram. Leiden 1979, 132-149) gathers together and thoroughly analyses a series of epigrams from the Hellenistic epoch that follow the famous model by 'Simonides'. Further considerations on the fame and reuse of the 'Simonidean' epitaph, and bibliographical references can be found in GARULLI, V.: Byblos Lainee. Epigrafia, letteratura, epitafio. Bologna 2012, 158-159 n. 280.

${ }^{9}$ See TARÁN (n. 8) 146. For a review of the recurrent elements in similar epigrams see TARÁN (n. 8) 148-149 n. 37.

${ }^{10}$ See Wilamowitz, U.: Sappho und Simonides. Untersuchungen über griechische Lyriker. Berlin 1913, 299. Also REITZENSTEIN (n. 2) 139 states that, though it appears as such, this is not an epitaph. 
epigram lies in the fact that, despite its formal structure, it surely does not contain a message of death to be sent to those in Mitylene, but the content of the message is the identity of the poetess, and the declaration of poetic kinship with the famous poetess from Mitylene. Nossis re-uses forms and topoi typical of epitymbia, with particular allusion to the famous 'Simonidean' epitaph, and reverses their functions by giving them poetic implications. In other words, Nossis uses the form of the auto-epitaph to compose a poetic manifesto. The combination of a sepulchral form with a programmatic content is not surprising. As highlighted by Männlein-Robert, ${ }^{11}$ Hellenistic selfepitaphs are normally focused not on details of the lives of their authors but on their representation as poets. They function as extended sphragides, where the poets not only present themselves, but their poetic work as well.

The recognition of self-epitaphs as a form of sphragis can also be related to the position that such epigrams probably occupied in poetic collections. Similarly to sphragides, it is normal to expect that in a book of epigrams self-epitaphs occupied a liminal position, such as the final one. ${ }^{12}$ The typically Hellenistic habit of closing one's collection with a self-epitaph displays, in fact, a fair number of parallels: such a function was meant to be carried out by Leon. AP VII 715 (HE 2529-2534), as well as by the two Callimachean epigrams $A P$ VII 525 (ep. 21 Pf. $=H E 1179-1184$ ) and $A P$ VII 415 (ep. 35 Pf. $=H E 1185 f$.). ${ }^{13}$ This tradition seems to have been widespread in Latin poetry, too, and examples can be found in Horace (Carm. III 30) and Propertius (I 22). ${ }^{14}$ The epitaphic form made it possible, whilst taking leave of the readers, to provide important information about the author. ${ }^{15}$ Furthermore, the choice of such a scheme can be correlated with the conception of poetry as a 'monument', ${ }^{16}$ which will survive over time and grant the poet eternal fame. In particular, Nossis chooses the specific model of those epitymbia that entrust the reader with the task of reporting a message. Such an image not only strengthens the idea of the wide circulation that

${ }^{11}$ See MÄnNLEIN-Robert, I.: Hellenistische Selbstepitaphien: zwischen Autobiographie und Poetik. In ERLER, M. - SCHORN, S. (eds): Die griechische Biographie in hellenistischer Zeit. Berlin 2007, 363 and 365. PEIRANO, I.: "Sealing" the book: the sphragis as paratext. In JANSEN, L. (ed.): The Roman Paratext. Frame, Texts, Readers. Cambridge 2014, 225f.

${ }^{12}$ On the habitual position of sphragides, see KRANZ, W.: Sphragis. Ichform und Namensiegel als Eingangs- und Schlußmotiv antiker Dichtung. RhM n. F. 104 (1961) 4.

${ }^{13}$ See also a series of Meleager's auto-epitaphs ( $A P$ VII $417=H E 3984-3993, A P$ VII $418=H E$ 3994-3999, $A P$ VII $419=H E$ 4000-4007, $A P$ VII $421=H E$ 4008-4021) which probably should have been at the end of each book of his Garland. See GABATHULER (n. 4) 48-49. On Hellenistic auto-epitaphs, see MÄNNLEIN-ROBERT (n. 11). In particular, MÄNNLEIN-ROBERT (n. 11) 366 asserts that Nossis' auto-epitaph was the first example of this Hellenistic genre. However, the difficulty of determining the chronological relations among early Hellenistic poets makes it impossible to establish an indisputable sequence.

${ }^{14}$ For an analysis of those two poems, see respectively PASQUALI, G.: Orazio lirico. Firenze 1920, 323 and Fedeli, P.: Sesto Properzio. Il primo libro delle elegie. Firenze 1980, 496-498, see also PEIRANO (n. 12) 231-242. For further examples in Latin literature, see GABATHULER (n. 4$) 49$ and PEIRANO (n. 12).

${ }^{15}$ See FEDELI (n. 14) 498. MÄNNLEIN-ROBERT (n. 11) in part. 363 considers auto-epitaphs as a form of autobiography.

${ }^{16}$ For an examination of the motif of exegi monumentum aere perennius (Hor. Carm. III 30. 1) and its fame, see Tosi, R. T.: Dictionnaire des sentences latines et grecques. Trad. fr. Grenoble 2010 (ed. or. Dizionario delle sentenze latine e greche, Milano 1991) 50. For further examples of this topos, see KERKHECKER, A.: Callimachus’ Book of Iambi. Oxford 1999, 11-13. 
the poetess wishes for her poetry, it also highlights the fact that the poetess is taking leave of her reader here.

The initial invocation ( $\tilde{\omega} \xi \varepsilon \tilde{\mathrm{iv}}$ ') recurs in an identical form in 'Simon.' $A P$ VII 249. 1

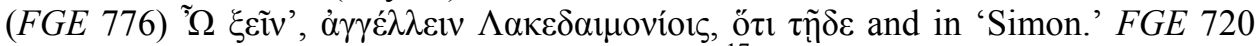

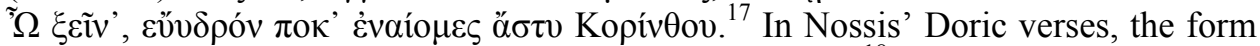
itself with the long vowel $\xi \varepsilon \tilde{v} v$ ', typical of the Ionic dialect ${ }^{18}$ and frequent in Homeric language, ${ }^{19}$ betrays the adhesion/allusion to such models.

The use of $\xi \varepsilon \tilde{v}$ o $\varsigma / \xi \varepsilon \dot{\varepsilon}$ o $\varsigma$ to identify the passer-by, who was the addressee of the epigram in sepulchral contexts mostly, ${ }^{20}$ is frequent both in epigraphic ${ }^{21}$ and literary $^{22}$ traditions, and it will become a habitual form of address in the Hellenistic era. ${ }^{23}$ The first occurrence of this formula dates back to the 'Simonidean' epitaph AP VII 249. 1 (FGE 776). ${ }^{24}$ More specifically, according to the reconstruction suggested by Tueller, ${ }^{25}$ the custom of designating the passer-by as $\xi \dot{\varepsilon} v o \varsigma$ is derived precisely from the two epitaphs quoted above. In both cases, the particular circumstance of the burial in a foreign land justifies the designation of those who read the epigraph as $\xi \dot{\varepsilon} v o 1$, 'strangers', if compared with the dead. Petrovic ${ }^{26}$ points to the fact that this use was probably connected to the peculiar cultural context of which such epigrams were part: the annual

${ }^{17}$ The second epigram - composed at the same time as the first one, around $480 \mathrm{BC}$, but dedicated to the Corinthians who fell at Salamis - is transmitted in Plut. Mal. Hdt. 870e and in [Dio Chrys.] 37. 18 entirely, whilst a part of the first two lines are preserved in CEG 131 (Salamis, 480 BC ]ONIO-

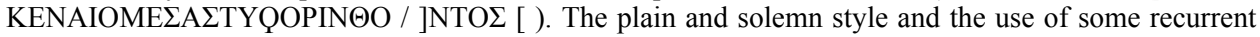
expressions allow us to identify a certain affinity with coeval official epitaphs composed in the memory of soldiers fallen in battle, e.g. for the Spartans killed at Thermopylae; see GARULLI (n. 8) 72. For an analysis of the whole epigram, see GARULLI (n. 8) 63-72.

${ }^{18}$ See PAGE, D. L.: Further Greek Epigrams. Cambridge 1981, 233.

${ }^{19}$ For an analysis of different consequences of the loss of the digamma after a consonant in Greek dialects and in poetic language, see NÖTHIGER, M.: Die Sprache des Stesichorus und des Ibycus. Zürich 1971, 26-28. Nossis seems to prefer forms without compensatory lengthening (see ǐ $\sigma \alpha A P$ VI $353.4=$

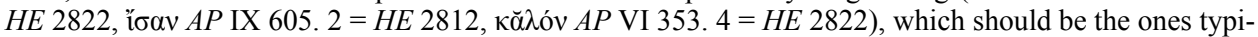
cal for the dialects of her region. However, the occurrence of $\kappa \bar{\alpha} \lambda$ óv (AP VI 275. $4=H E 2810)$ gives evidence of an alteration which is well documented by the poetic usage of her contemporaries and predecessors and which already appeared, in primis, in the language of the Homeric epos.

${ }^{20}$ The use in sepulchral contexts is not the only one possible: see e.g. Antip. Thess. AP IX 76. 6 (GPh 520). See NERI, C.: Erinna. Testimonianze e frammenti. Bologna 2003, 200 and Gow-PAGE (n. 4) II 80. For other examples of the same invocation in some epideictic epigrams see GEOGHEGAN, D.: Anyte. The Epigrams. Roma 1979, 161.

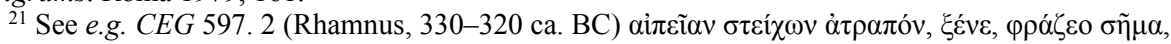

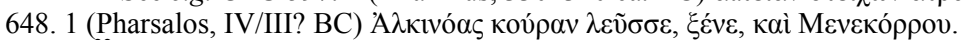

${ }^{22}$ See e.g. Antip. Sid. $A P$ VII 6. 4 ( $H E$ 227), Perses $A P$ VII 445. 1 (HE 287), Heraclitus $A P$ VII 465. 5 (HE 1939).

${ }^{23}$ See Gow-Page (n. 4) II 38 and Tueller, M. A.: The Passer-by in Archaic and Classical Epigram. In Baumbach, M. - Petrovic, A. - Petrovic, I. (eds): Archaic and Classical Greek Epigram. Cambridge 2010, 51.

${ }^{24}$ See ErBSE, H.: Zu den Epigrammen des Simonides. RhM n. F. 141 (1998) 216: "Vermutlich ist

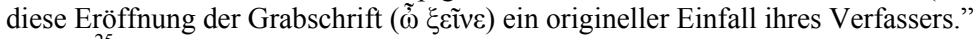

${ }^{25}$ Tueller (n. 23) 51-54. See also TuELler, M. A.: Look Who's Talking. Innovations in Voice and Identity in Hellenistic Epigram. Leuven 2008, 44-46.

${ }^{26}$ See Petrovic, A.: Kommentar zu den simonideischen Versinschriften. Leiden 2007, 248-249. 
rituals for the fallen Spartiates and Corinthians were meant to ensure a constant flow of $\xi \varepsilon i v v o r$ to the commemoration place. The fame of the two poems (which perhaps were among the first to be circulated autonomously from their original stone) has probably contributed to the spread of such an appellation, which then became topical. ${ }^{27}$ The formula, in any case, was perceived as particularly suitable for the epitaphs dedicated to those buried in a foreign land, as in [Theocr.] AP VII 660 (HE 3426-342) ${ }^{28}$

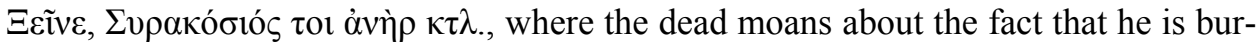
ied away from home. In Nossis' poem, therefore, such a beginning, regardless of the precise reminiscence of a widely known incipit, contributes to creating in the reader the impression - confirmed in the first couplet but then neglected - that this epitaph commemorates somebody who died far from his/her homeland. ${ }^{29}$

On the other hand, within the bookish context of Nossis' liber, the $\xi \varepsilon i v o s$ of the first line can be identified as the reader of her collection of epigrams. ${ }^{30}$ This use is borrowed from a poem by Anyte, in which the reader, represented as a traveller, is metaphorically invited to rest in the act of reading, as if this was a breezy clearing:

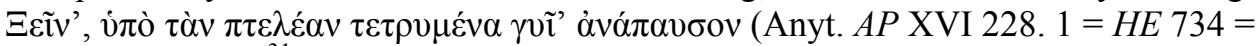
ep. 18. 1 Geogh.). ${ }^{31}$ The identification of the addressee of the epigram with a cultured reader and lover of poetry is also confirmed by the first couplet, where Nossis lingers on the characterisation of what traditionally was an anonymous figure. ${ }^{32}$ According to Gutzwiller, ${ }^{33}$ such a description specifically identifies an aspiring poet, ${ }^{34}$ to whom the poetess entrusts the task of spreading her fame. In this way, Nossis intends to claim her place within the poetic tradition, presenting herself as a sort of mediator between Sappho's poetry and those who, after her, will gain inspiration from the poems of the poetess from Mytilene.

After the invocation to the stranger, the temporal-conditional sentence ci $\tau$ v $\gamma \varepsilon$ $\pi \lambda \varepsilon i \tilde{\varsigma}$ expresses the prospect of a journey. Such a syntactic scheme is frequent in those

\footnotetext{
${ }^{27}$ Lattimore states, however, that the apostrophe to the traveller should be correlated with the fact that the tombs were outside the city; see LATTIMORE, R.: Themes in Greek and Latin Epitaphs. Illinois Studies in Language and Literature 228/1-2 (1942) (= Urbana, Ill. 1962), 230. Concerning this topic, Bing observes that beyond the traditional walls of the city anyone could be recognised as $\xi \dot{\varepsilon} v o r$; see BING, P.: Theocritus' epigrams on the statues of ancient poets. $A \& A 34$ (1988) 119 n. 9. For further bibliographical references, see TUELLER (n. 23) 51.

${ }^{28}$ For the discussion of the paternity of the epigram, see Gow, A. S. F: Theocritus. Cambridge 1950 , II 535.

${ }^{29}$ See Acosta-Hughes, B. - BArbantani, S.: Inscribing Lyric. In BING, P. - Bruss, J. S. (eds): Brill's Companion to Hellenistic Epigram. Down to Philip. Leiden-Boston 2007, 445-446.

${ }^{30}$ Cf. GutZWiller (n. 2) 86.

${ }^{31}$ On the programmatic value of such an epigram and on the numerous later re-uses, see GUTZWILLER (n. 2) 71-74. An echo of the same epigram by Anyte can be found elsewhere in Nossis in $A P \mathrm{~V}$ 170 (HE 2791-2794), namely in another poem that is considered to be programmatic and is usually identified with the proemium of Nossis' libellus. On this, see GUTZWILLER (n. 2) 72, 76-77.

${ }^{32}$ In a Theocritean epigram dedicated to Anacreon, the apostrophe $\tilde{\omega} \xi \varepsilon \varepsilon \varepsilon$ (Theocr. AP IX599. $1=$ $H E$ 3440) seems to refer, as in this case, to a selected and educated audience. See BING (n. 27) 117-118.

33 See GuTZWILLER (n. 2) 86.

${ }^{34}$ This is, in any case, a universal characterisation. Cazzaniga's attempt to identify the addressee of the poem with a historical character seems therefore vain; see CAZZANIGA (n. 4) 438-439. See TARÁN (n. 8) 146 n. 32.
} 
Hellenistic epigrams that develop the motif of conveying a message, usually a mournful one, to some faraway land. Examples of this use are found in Asclep. AP VII 500. 2

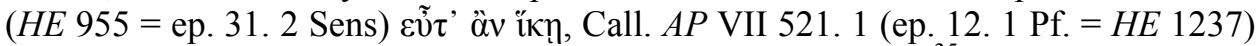

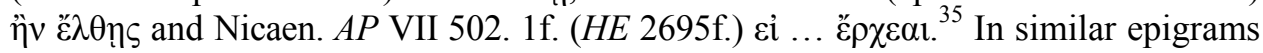
it is not unusual to find a reference to sailing, since the motif is often re-used in epitaphs for the shipwrecked who ask for the news of their death to be reported home. ${ }^{36}$ See e.g. Call. $A P$ VII 272. 6 (ep. 18. 6 Pf. $=H E$ 1224) v $\alpha v \tau i ́ \lambda \varepsilon$, Theaetet. $A P$ VII 499.

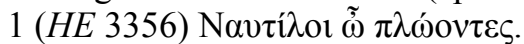

The first divergence between Nossis' self-epitaph and the other epigrams that follow the 'Simonidean' model lies in the fact that the destination of the journey - and of the message - is normally expected to coincide with the homeland of the deceased. In this case, however, Mytilene, the city to which the message is sent, is not the poetess' motherland. Nossis' homeland will be declared only at the end of the second hex-

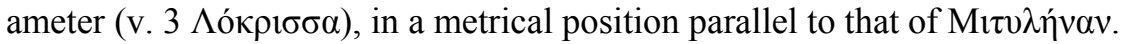

Mytilene must rather be interpreted as the poetic homeland of Nossis, as is made clear by the acknowledgement of the city as Sappho's motherland. Moreover,

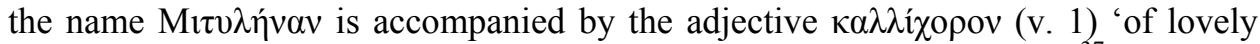
dances', 'of lovely choirs'. Although, from the Homeric poems onwards, ${ }^{37}$ the adjective is employed as a conventional epithet for cities, in Nossis the adjective does not seem purely ornamental. Such a characterisation recalls the world of Sapphic poetry ${ }^{38}$ and its performances by a choir of parthenoi, which probably affected at least some poems of the poetess from Mitylene. ${ }^{39}$ The juxtaposition of Sappho's poetry with choirs made up of young women and dances is not a unicum in epigrammatic poetry. This image can be found elsewhere in Posidippus (ep. 51 A.-B.), ${ }^{40}$ as well as in an anonymous epigram from the Alexandrian $\operatorname{epoch}^{41}$ (AP IX $189=F G E$ 1176-1181),

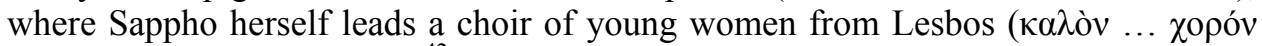
$A P$ IX 189. $3=F G E$ 1178). ${ }^{42}$ Therefore, in this case, the re-use of the Homeric epi-

\footnotetext{
${ }^{35}$ See TARÁN (n. 8) 146 and Di MARCO, M.: Un motivo dell'epigramma funebre in Sofocle (Ai. 845-851). MD 38 (1997) 148.

${ }^{36}$ This is also the case, for example, in Asclep. $A P$ VII 500 (HE 954-957=ep. 31 Sens), Call. $A P$ VII 272 (ep. 18 Pf. = HE 1219-1224), Theaetet. $A P$ VII 499 (HE 3356-3359).

${ }^{37}$ See $O d$. XI 508; H. Hom. 15. 2; Bacch. 5,106; 'Simon.' VII 254. 3 (FGE 890).

${ }^{38}$ Moreover, $\kappa \alpha \lambda$ ó $\varsigma$ is one of the most recurrent terms in Sappho, in order to define what is sensual, see LANATA, G.: Sul linguaggio amoroso di Saffo. QUCC 2 (1966) 74.

${ }^{39}$ This should be the case of the wedding poems, see STEHLE, E.: Performance and Gender in Ancient Greece. Nondramatic Poetry in Its Setting. Princeton 1997, 277-280. For further considerations and bibliography, see BATTEZZATO, L.: Song, performance, and text in the new Posidippus. ZPE 145 (2003) 38.

${ }^{40}$ The specific allusion to Sappho is defended by BATTEZZATO (n. 39) 40 and by AcostAHughes, B.: Arion's Lyre: Archaic Lyric into Hellenistic Poetry. Princeton 2010, 91-92, whilst other scholars prefer a more general interpretation such as 'songs in the style of Sappho'. For an analysis of the topic, with appropriate bibliography, see BATTEZZATO (n. 39) 40.

${ }^{41}$ Cf. PAGE (n. 18) 338.

${ }^{42}$ In the Ilias (IX 129) already, it is possible to find a reference to the performance of choral dances by women in Lesbos, in ritual contexts. For a collection of testimonies regarding this, see PAGE (n. 18) 337.
} 
thet $\kappa \alpha \lambda \lambda i$ í $0 \rho \rho$ takes on specific poetic allusions: ${ }^{43}$ from the beginning the city of Mitylene is identified as a city of art, where the poetry of its great poetess still reverberates. ${ }^{44}$

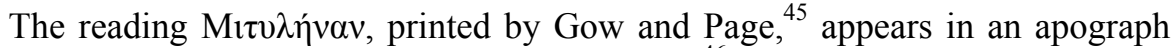
codex from the 17th/18th c. (Ap. codicis Buheriani). ${ }^{46}$ Most modern editors ${ }^{47}$ prefer

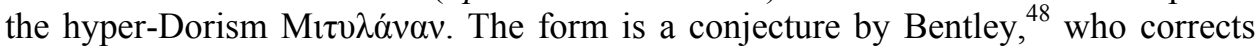

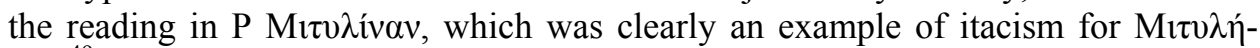

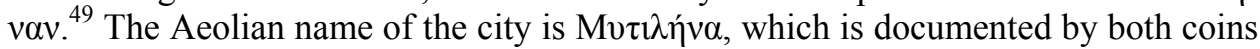

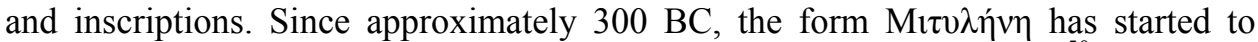
spread, and this will be the predominant form in medieval manuscripts. ${ }^{50}$ According

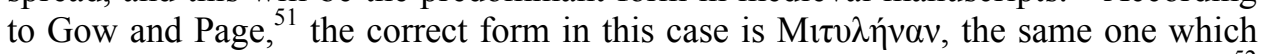
can be found in the most influential Theocritean manuscripts (Theocr. 7. 52 and 61), ${ }^{52}$

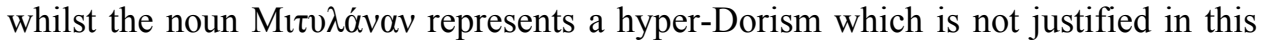
case.

In the second verse, Sappho's name ( $\left.\Sigma \alpha \pi \varphi \sigma^{\prime} \varsigma\right)$ appears in a symmetrical posi-

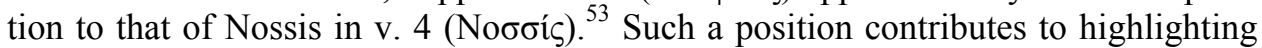
the strong relation between the two poetesses, which Nossis claims. More specifically, in the context of the - at least illusory - epitymbion, the presence of Sappho's name, instead of the expected name of a relative, ${ }^{54}$ depicts Nossis as a direct descendent of

${ }^{43}$ See SKInNER: Sapphic Nossis (n. 4) 1; BOWMAN (n. 4) 40-41; and ACOSTA-HuGHES-BARBANTANI (n. 29) 446. The adjective, as the epithet of a city, also preserves its etymological sense in Pind. P. 12. $26 \kappa \alpha \lambda \lambda i ́ \chi о \rho o v . . . \pi$ ó $\lambda \imath v$ X $\alpha \rho i \tau \omega v$. With regard to the association of the term to female choirs, see

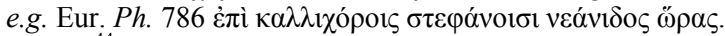

${ }^{44}$ For details on the possibility of reruns of the Sapphic songs in the following eras, see BATTEZZATO (n. 39) 38 in particular n. 57. It is, however, not necessary to think that the adjective $\kappa \alpha \lambda \lambda i$ ío $\rho \circ \varsigma$ implies current re-performances of the Sapphic poems.

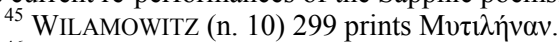

${ }^{46}$ The codex contains a selection of epigrams from the Anthologia Palatina compiled by J. BOUHIER (1673-1746) and preserved at Göttingen, in a copy by J. G. SCHNEIDER. Other copies of this apograph can be found in Paris and one of them (Par. suppl. gr. 557) contains annotations by Guyet and Salmasius, alongside those of Bouhier. See Gow-PAGE (n. 4) I xliv.

${ }^{47}$ The form is accepted by BRUNCK (n. 4) 196, MEINEKE (n. 4) 9, WALtz (n. 4) 158 and BECKBY

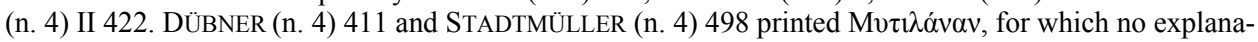
tions are provided either in the commentary or in the critical apparatus which accompany the two editions, respectively.

${ }^{48}$ See Bentley, R.: A Dissertation upon the Epistles of Phalaris. London 1699, 355. Generally (see StAdTMÜLler [n. 4] 499; WALtZ [n. 4] 158; BECKBY [n. 4] II 422; GOW-PAGE [n. 4] I 154), the conjecture has been erroneously attributed to Toup (see TouP, J.: Emendationes in Suidam et Hesychium, et alios Lexicographos Graecos. IV Oxonii 1790, 146), who quotes the text by Wolf (see WoLF, I. C.: Poetrarium octo Erinnae, Myrus .... Hamburgi 1734, 84), who in turn refers back to Bentley.

${ }^{49}$ See GallaVotTi (n. 4) 242.

${ }^{50}$ See HerBST, R. s.v. Mytilene in PWRE XVI/2 (1935) 1411-1412.

${ }^{51}$ See Gow-PAGE (n. 4) II 442.

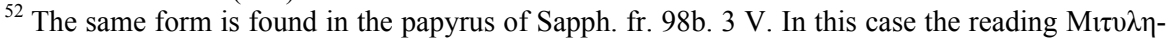

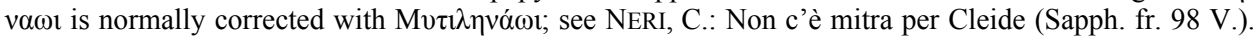
Eikasmos 23 (2012) 36, n. 32.

${ }^{53}$ See ACOSTA-Hughes (n. 40) 86.

${ }^{54}$ See Bowman (n. 4) 40. As it emerges from Theophr. Char. 13. 10, an epitaph for a woman usually contained little information and this was mainly limited to her father's or her husband's name. The 
the poetess from Mitylene. In other words, Nossis profits from the norms of sepulchral epigrams to present herself as Sappho's heir.

In the third verse, as in 'Simon.' $A P$ VII 249. 1 (FGE 776), the invitation to

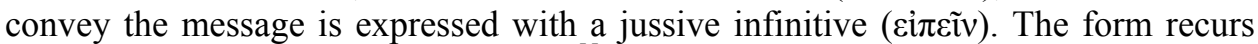
identically, in the same metrical place, ${ }^{55}$ in two other epitaphs that develop the same motif as the famous 'Simonidean' epigram: ${ }^{56}$ Nicaen. $A P$ VII 502. 3 (HE 2697) and Theaetet. AP VII 499. 3 (HE 3358). ${ }^{57}$

After the infinitive, the recourse to indirect speech (introduced by $\dot{\omega} \varsigma$ ) represents, according to Tarán, ${ }^{58}$ one of the stylistic traits recurrent in the epigrams that ask for a message to be delivered. The construction seems to date back once again to the epitaph for the fallen at Thermopylae: $\alpha \gamma \gamma \varepsilon \dot{\varepsilon} \lambda \lambda \varepsilon ı v \Lambda \alpha \kappa \varepsilon \delta \alpha \mu$ ovíoıs, ö $\tau \imath \tau \tilde{\eta} \delta \varepsilon$ ('Simon.' $A P$ VII 249. $1=F G E$ 776). In particular, Nossis partially modifies the 'Simonidean' model by omitting the indication, in the form of a dative, of the addressee of the message, i.e. of whoever will normally mourn the dead. ${ }^{59}$ On the contrary, Nicaenetus and

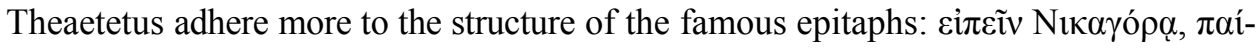

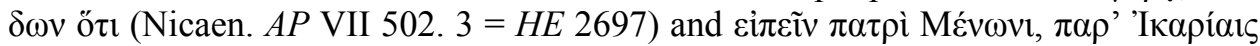
ö $\tau$ (Theaetet. $A P$ VII 499. $3=H E$ 3358). In both cases, the infinitive is followed first by the dative of the addressee and then by the declarative conjunction ö $\tau$.

The declarative conjunction is repeated in the fourth verse - in the form ö $\tau$ in order to introduce a new piece of information that the passer-by will have to deliver to Mitylene, according to the model already pointed out. The repetition of the declarative conjunction was a typical feature of archaic epigrams and is found in the self-epi-

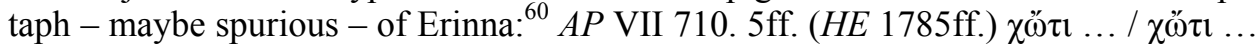

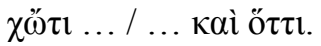

The impression that Nossis is presenting herself as a direct descendant of Sappho

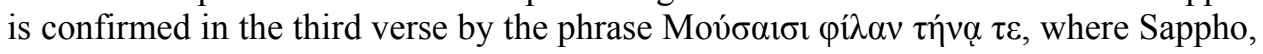
together with the Muses, seems to mourn the death that the reader expects to be announced. The adjective $\varphi$ í $\lambda$ o $\varsigma$ is frequent in sepulchral epigrams, where the deceased is presented as 'dear/beloved' to those who mourn their loss. ${ }^{61}$ As Bowman notes in connection with a constant subversion of the paradigms of the canonical epitymbion,

mention of the mother's name and her place of birth were considered to be unnecessary and generally aimed at obtaining particular pathetic effects. See BOWMAN (n. 4$) 40$ and 53-54 n. 11, 12, 13; FANTUZZI, M. - Hunter, R.: Tradition and Innovation in Hellenistic Poetry. Cambridge 2004 (or. ed. Muse e modelli: la poesia ellenistica da Alessandro Magno ad Augusto, Roma 2002) 292. Further considerations and bibliographic references in DigGLE, J.: Theophrastus. Characters. Cambridge 2004, 330-331.

55 The similarity of the structure is emphasised by the fact that both epitaphs, like Nossis', are in quatrains and in elegiac distichs.

${ }^{56}$ Cf. TARÁN (n. 8) 148 n. 37.

${ }^{57}$ In other epigrams related to the same model, the invitation is normally expressed with the imperative, see Asclep. AP VII 500. 1 (HE $954=$ ep. 31. 1 Sens) عĩ $\pi$ ov, Call. $A P$ VII 521.3 (ep. 12. 3 Pf. =

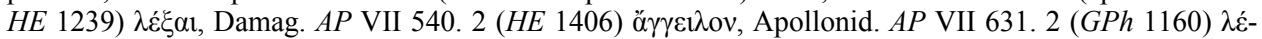
$\xi \alpha \tau \varepsilon$.

\footnotetext{
58 TARÁN (n. 8) 147.

${ }^{59}$ In the epitaph of Nossis this role seems to be undertaken by the Muses themselves, see infra.

${ }^{60}$ See NERI (n. 20) 431.

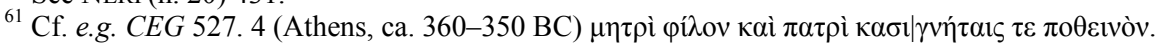


in the pseudo-epitaph which Nossis composes for herself, the Muses - and Sappho take the place of the traditional mourners. ${ }^{62}$

The phrasing pí $\lambda \alpha \nu \tau \eta \dot{v} \alpha \varepsilon$ seems the most reasonable reading of the incomprehensible $\varphi$ í $\lambda \alpha \tau \tilde{\eta} v \alpha \imath \tau \varepsilon$ transmitted. ${ }^{63}$ The form $\varphi \dot{i} \lambda \alpha \nu$, which can already be found in the margin of the apograph Ap.B., appears in Brunck's edition. ${ }^{64}$ It is plausible that the following dative ( $\tau \tilde{\eta} v \alpha)$ ) refers to pí $\lambda \alpha \nu$, in parallel with the previous Moṽ-

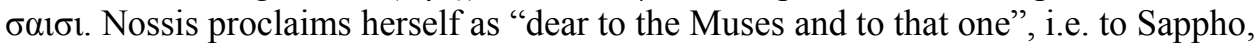
mentioned in v. 2. This is what the Lemmatist of the Palatine codex probably read, perhaps deducing from the explicit declaration of philia the news that Nossis was the

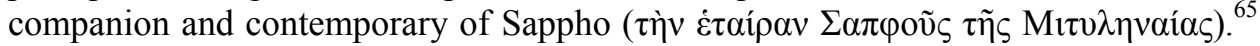
It is evident that the Lemmatist's interpretation, which is clearly too literal, must be rejected: the bond that connects Nossis to the great poetess from Mitylene is the same which links Nossis to the Muses. Sappho, like the Heliconian goddesses, grants her favour to the Locrian poetess and represents a source of inspiration for her verses. In accordance with the Hellenistic habit of choosing an illustrious predecessor who works together with - or substitutes - the divine inspirer, Sappho is placed beside the Muses and shares their role. ${ }^{66}$ Moreover, the assimilation of Sappho to the Muses is a topos in the epigrams that celebrate her, in which the poetess is often presented as the tenth Muse. $^{67}$

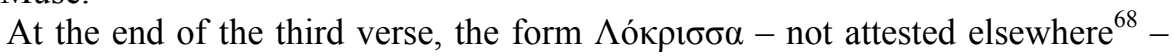
has been considered corrupted by the majority of modern editors and, from Brunck

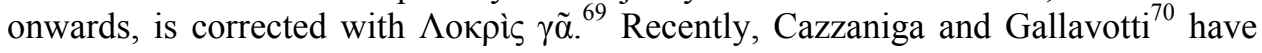

${ }^{62}$ BowMAN (n. 4) 41.

${ }^{63}$ Starting from $\varphi \hat{i} \lambda \alpha \tau \tilde{\eta} v \alpha \iota \tau \varepsilon$, the text transmitted in $\mathbf{P}$ is corrupted in several points up to the half of the following line. Numerous are the conjectures which have included most of the final couplet, until the edition by Gow and Page, in which the entire passage, from $\dagger \varphi$ í $\lambda \alpha$ to ö $\tau \mu$ ot $\dagger$, is printed between cruces. A review of the several emendations proposed can be found in STADTMÜLLER (n. 4$) 499$ and CAZZANigA (n. 4) 431 n. 1. To this long series the more recent interventions by CAZZANIGA (n. 4) 437 ( must be added. The text proposed here was printed for the first time by GUTZWILLER (n. 2) 85, who substantially keeps the transmitted text, limiting herself to combine subtle conjectural interventions.

${ }^{64}$ See BRUNCK (n. 4) 196. Brunck, however, relates the dative $\tau \eta \dot{v} \alpha$ to the conjectural í $\sigma \alpha v$ of

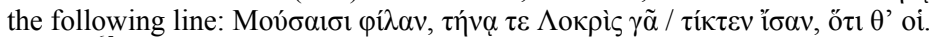

${ }^{65}$ See Gallavotti (n. 4) 247-248 and SkinNER: Sapphic Nossis (n. 4) 12 n. 21.

${ }^{66}$ See FANTUZZI-HUNTER (n. 54) 1-17. In particular, the declaration of an illustrious model/predecessor is found in those poetic genres that do not have an established tradition behind them - or at least not apparently; see FANTUZZI-HUNTER (n. 54) 3-4.

${ }^{67}$ The motif already appears in the most ancient epigram on Sappho ('Plat.' $A P$ IX $506=F G E$ 624f.), see also Diosc. VII 407. 2ff. (HE 1565f.), Antip. Sid. $A P$ VII 14. 1f. (HE 236f.) and $A P$ IX 66. 2 (HE 245), anon. $A P$ IX 571. 7f. (FGE 1210f.). Cf. PAGE (n. 18) 173 and ACOSTA-HugHES-BARBANTANI (n. 29) 433 and 438.

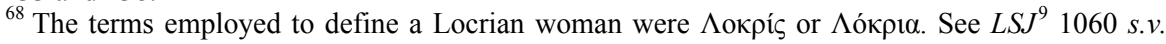

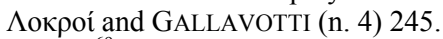

${ }^{69}$ The correction is widely accepted by all later editors (see MEINEKE [n. 4] 9; DÜBNER [n. 4] 411; Stadtmüller [n. 4] 499; PAton, W. R.: The Greek Anthology. Vol. II. London - Cambridge, Mass. 1917, 382; GEFFCKEN, J.: Griechische Epigramme. Heidelberg 1916, 100; GABATHULER [n. 4] 7; WALTZ [n. 4] 158; BeCKBY [n. 4] II 422; PAGE, D. L.: Epigrammata Graeca. Oxonii 1975, 70). It is not possible to find confirmation of the claim of Jacobs (see JACOBS, F.: Animadversiones in epigrammata 


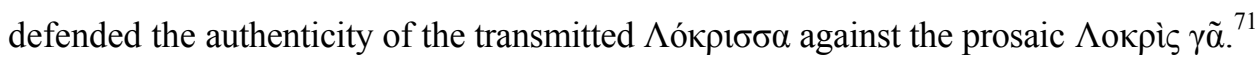
The enigmatic form is likely to be a neo-formation, which contributes to rendering the tone of the passage more solemn, with the introduction of an unusual term in place of the plain $\Lambda$ oкpís. The new ethnic name ${ }^{72}$ is formed with the suffix $-1 \sigma \sigma \alpha,{ }^{73}$ which starting from the Hellenistic era experiences a certain spread as a feminine formant, firstly for proper nouns and ethnic groups and then for common nouns. ${ }^{74}$

The mention of the Locrian origin in the epigram is in a parallel position to the

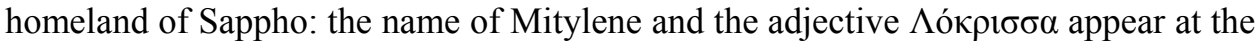
end of the first and second hexameter respectively. ${ }^{75}$ The effectiveness of the paral-

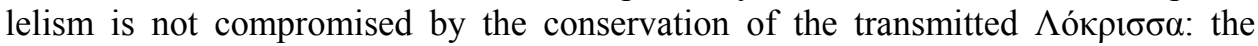
choice of the ethnic instead of the toponym represents rather an example of variatio, without the comparison between the two homelands of Nossis - one anagraphical and the other poetic - being weakened.

Regarding the use of personal names, the absence of the name of Nossis' mother

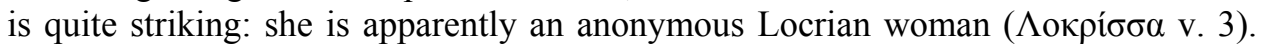
However, in the frame of a book, i.e. of a volumen of Nossis' epigrams, the name of the mother - Theophilis, not explicitly indicated here - can be retrieved in the same

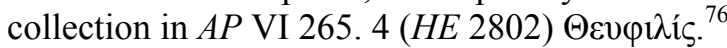

At the beginning of the last verse, the transmitted $\tau$ ík $\tau \varepsilon \imath v$ is probably due to a simple confusion of the copyist with the ending of $\varepsilon i \pi \varepsilon \mathrm{i} v$ in the line that immediately precedes it. ${ }^{77}$ The imperfect $\tau$ ík $\tau \varepsilon v$, together with $\tau^{\prime}$ í $^{\prime} \tau^{\prime}$ '̌ $\mu$ ', appears in the margin in Ap.B., where it is plausibly a conjectural attempt of correction. ${ }^{78}$ Meineke replaces

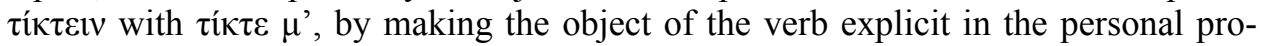

Anthologiae Graecae secundum ordinem analectorum Brunckii. Lipsiae 1798 I/1 420), who states that

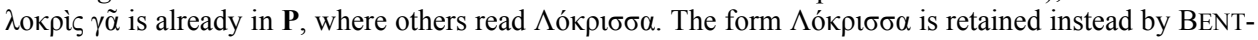
LEY (n. 48) 355 and WOLF (n. 48) 84.

${ }^{70}$ See CAZZANigA (n. 4) 432-433 and GALlaVotTi (n. 4) 245-246.

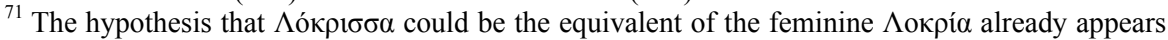
in Holstenius (see HolsteniUs, L.: Notae et Castigationes in Stephanum Byzantium De Urbibus. Lugduni Batavorum 1692, 191), who reports the epigram of Nossis in his commentary notes for the work by

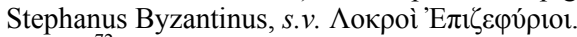

${ }^{72}$ For GALlavotTi (n. 4) 245 the form is a name, whilst for CAZZANiGA (n. 4) 433 it is an adjective, which should agree with the conjectural roín.

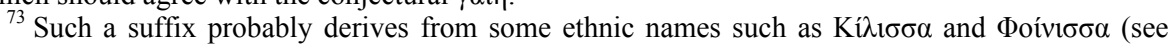
Chantraine, P.: La formation des noms en Grec Ancien. Paris 1933, 109) or is a neo-formation, starting from the ethnic -ís.

${ }^{74}$ Cf. Chantraine (n. 73) 109-110; CAzZAniga (n. 4) 433; Gallavotti (n. 4) 245-246.

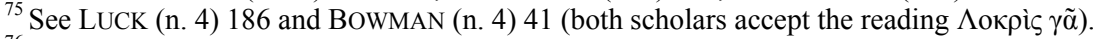

${ }^{76}$ A similar example of such a complementarity is shown by the two Callimachean epitaphs $A P$ VII 525 (ep. 21 Pf. $=H E$ 1179-1184) and $A P$ VII 415 (ep. 35 Pf. = HE 1185f.), dedicated respectively to the father of Callimachus and Callimachus himself. In the first one, the name of the father (Batto) is omitted, yet the name appears in the second epitaph. On the contrary, the name of Callimachus appears in the epytimbion of the father and not in his own.

${ }^{77}$ Cf. GallavotTi (n. 4) 242.

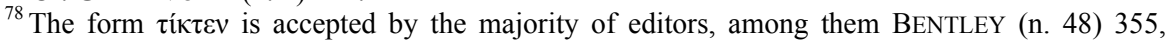
BRUNCK (n. 4) 196, DÜBNER (n. 4) 411, PATON (n. 69) 382, BECKBY (n. 4) II 422. 
noun. The conjecture is accepted by Page ${ }^{79}$ but is rejected by Cazzaniga, ${ }^{80}$ who finds the reduction of the pronoun to a single consonant at the end of the phrase inappropriate. $^{81}$ In this case, the object could be retrieved from the context, as well as from the $\mu \mathrm{or}$ immediately following. What is more, such an omission seems to highlight the accusative $\varphi$ í $\lambda \alpha v$, which contains the most significant information about the identity of the poetess. Moreover, the omission of the personal pronoun has several parallels in Greek poetry, when in the sentence this is the element «più ovvio e dunque anche più facilmente sottintendibile». ${ }^{82}$

Meineke was the first to see the form íoals (v. 4) as a participle of the Doric verb í $\sigma \alpha \mu{ }^{83}$ and he was later followed by most editors. ${ }^{84}$ The typically Doric perfect displays, in this case, the participial ending - $\alpha \iota \varsigma$, typical of the Aeolian dialect. ${ }^{85}$ The combination of different dialectal traits ${ }^{86}$ and the choice of an ending with the typical Aeolian diphthongisation ${ }^{87}$ are not surprising in Nossis' verses, contrary to what Cazzaniga and Gallavotti ${ }^{88}$ argue. The latter believes that it is rather the second person of

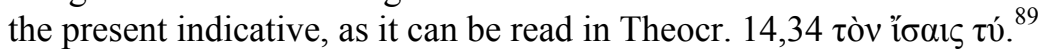

In this case, the presence of a participle can be related to the model employed in the oldest funerary epigraphs, where the verb of movement in the imperative is normally accompanied by a participle that expresses the type of homage demanded of

${ }^{79}$ See PAGE (n. 69) 70.

${ }^{80}$ CAZZANiga (n. 4$) 434$ n. 9.

${ }^{81}$ Similar observations are confirmed by GALLAVOTti (n. 4) 247.

${ }^{82}$ See NeRI, C. - CitTI, F.: Sudore freddo e tremore (Sapph. fr. 31,13 V. $\sim$ Sen. Tro. 487s. $\sim$ Apul. Met. I 13, II 30, X 10). Eikasmos 16 (2005) 51-62 (see also 57-58 for further examples of this omission in Greek poetry).

${ }^{83}$ The verbal form derives from a simplification of the inflection of oĩ $\delta \alpha$, which in Doric occurred with the extension of an analogic form i $\sigma \alpha-$-, acquired from the third person plural î $\sigma \alpha v \tau 1$, see HEILMANN, L.: Grammatica storica della lingua greca. Torino 1963, 231 and BEEKES, R.: Etymological Dictionary of Greek. Leiden-Boston 2010, 599 s.v. i̋ $\sigma \bar{\alpha} \mu \mathrm{t}$. Variations of $\iota^{\sigma} \sigma \mu \mathrm{u}$ are documented in both literature and inscriptions. See $L S J^{9} 836$ s.v. "̌ $\sigma \bar{\alpha} \mu$ and CAZZANIGA (n. 4) 435.

${ }^{84}$ The interpretation of MEINEKE (n. 4) 97 is followed by DÜBNER (n. 4) 411, GEFFCKEN (n. 69) 100, Gabathuler (n. 4) 7, Waltz (n. 4) 158, BeckBy (n. 4) 422, PAGe (n. 68) 70. Bentley (n. 48) 355 interprets the form as an accusative plural with Doric or Aeolian ending, which is the equivalent of

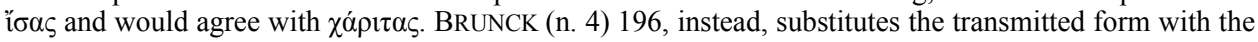
accusative '̌́av (

${ }^{85}$ See Tribulato, O.: La lirica monodica. In CASSiO, A. C. (ed.): Storia delle lingue letterarie greche. Roma 2008, 152-153. Other examples can be found in Sappho and Alcaeus, cf. GALLAVOTTI, C.: La lingua dei poeti eolici. Bari-Napoli 1948, 106-107.

${ }^{86}$ The epigrams of Nossis are generally characterised by the combination of forms typical of different dialects and such a combination occurs even within the same word, as in $\pi \alpha \dot{\chi} \chi \varepsilon \alpha \varsigma$ ( $A P$ VI 132. $4=$

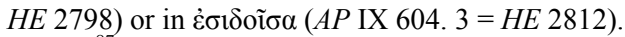

${ }^{87}$ On the other hand, forms of the participle in -alc seem to appear in Pindar, even if they are suspected to be originated by accidents of the manuscript tradition, see TRIBULATO, O.: La lirica corale. In CASSio (n. 84) 186 and TRIBUlato, O.: Literary dialects. In BEKKER, J. (ed.): A Companion to the Ancient Greek Language. Oxford 2010, 395.

${ }^{88}$ See CAZZANiga (n. 4) 435-436 and Gallavotti (n. 4) 247.

${ }^{89}$ CAZZANiga (n. 4) 436 suggests that the form is rather a jussive subjunctive. In both cases, however, the syntax would seem to be too fragmented by the succession of three periods in the final couplet. The hypotheses of the two scholars are rightly criticised by TARÁN (n. 8) 147. 
the passer-by. ${ }^{90}$ Furthermore, the participial form could conceal a veiled reference to $A P$ V 170 (HE 2791-2794). The reader of the collection of Nossis' epigrams has indeed already learned the name of the poetess ${ }^{91}$ and the meaning of the perfect participle leaves the possibility open that the $\xi \varepsilon i v o \varsigma$ already knows it, unlike what is suggested by the exhortatory form which instead appears to introduce a completely unprecedented piece of information. ${ }^{92}$

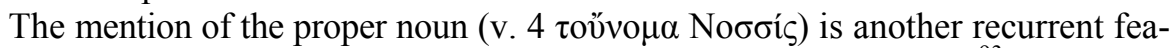
ture in funerary epigrams that develop the motif of reporting a message. ${ }^{93}$ In general, the indication of the name represents a fundamental element in epitaphs, where the identity of the deceased is often the main piece of information. ${ }^{94}$ In Asclep. AP VII

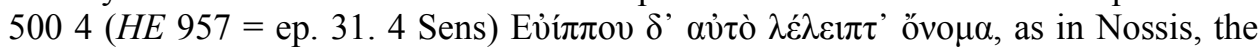
name of the deceased is only revealed in the last line of the poem, after a progressive unveiling of news which culminates in the identification of the dead, of whom nothing remains but his name. ${ }^{95}$ The term övo $\mu \alpha$ is, in fact, particularly frequent in the epytimbia intended for cenotaphs, where, in the absence of the body, the name is the only guarantee of an adequate mourning. ${ }^{96}$

The epigram closes with the imperative $10 \mathrm{u}$ (v. 4). After the invitation to report her message, Nossis invites the $\xi$ sivo to go, re-using in this way one of the typical elements of sepulchral epigraphs. ${ }^{97}$ The same verbal form can be found, for example, in two epitaphs from the 3rd c. BC: GVI 922.7 (Corcyra?, ante $227 \mathrm{BC})^{98} \dot{\alpha} \lambda \lambda^{\prime} \imath^{\prime} \mathrm{i} \mathrm{c}$

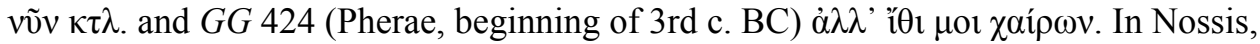
the almost isolated position of the imperative at the end of the line highlights the movement of the reader and stresses its importance. It is essential that the readers follow their own path: only in this way can they deliver the message entrusted to them by the poetess. ${ }^{99}$

In conclusion, Nossis employs the scheme of the auto-epitaph, but bends it to the expression of an original content. This model allows the poetess to amplify the impact of her poetic manifesto, which is likely to have occupied a prominent position at the end of Nossis' liber. A well-balanced play of parallelisms and cross references cuts through the whole epigram, and great attention is devoted to the arrangement of

${ }^{90}$ Cf. Tueller (n. 25) 63. The model is adopted by Nossis in $A P$ VII 414. 1 (HE 2827).

${ }^{91}$ The name is repeated in $A P$ VI 265. 4 (HE 2802).

${ }^{92}$ Another possibility is that í $6 \alpha 15$ is a present, second person singular, such as in Theocr. 14. 34 (see Gow [n. 28] II 113). Even in this case, however, the syntax would seem to be too fragmented by the succession of three periods in the final couplet.

${ }^{93}$ Cf. TARÁN (n. 8) 149-150 n. 37.

${ }^{94}$ The name of the deceased woman was one of the few pieces of information that appear on the epytimbia dedicated to women. Cf. BOWMAN (n. 4) 40 and FANTUZZI-HUNTER (n. 54) 292.

${ }^{95}$ Cf. TARÁN (n. 8) 133-134.

${ }^{96}$ Cf. e.g. Call. $A P$ VII 271. 4 (ep. 17. 4 Pf. $=H E$ 1248), Call. $A P$ VII 272. 4 (ep. 18.4 Pf. $=H E$ 1222), Phan. $A P$ VII 537. 3 (HE 3020). Cf. TARÁN (n. 8) 133 n. 6.

${ }^{97}$ Cf. Tueller (n. 25) 63 and 67.

${ }^{98}$ Cf. KAIBEL, G.: Epigrammata Graeca ex lapidibus conlecta. Berolini 1878, 66 and GEFFCKEN (n. 69) 73.

${ }^{99}$ Cf. TUeLler (n. 25) 67. 
the content, in order to amplify the surprise effect deriving from the subversion of the message contained in what appears to be, only on the surface, an auto-epitaph. Mitylene and Sappho, we are told in the last couplet, represent nothing more than Nossis' ideal homeland, the poetic model to which she is inclined.

Flavia Licciardello

Humboldt Universität zu Berlin

Excellence Cluster Topoi

Germany

flavia.licciardello@hu-berlin.de 